\title{
TURISMO E DESENVOLVIMENTO LOCAL: UM ESTUDO NOS MUNICÍPIOS DE UNIÃO DA VITÓRIA - PR; PORTO UNIÃO - SC E PORTO VITÓRIA - PR ${ }^{1}$.
}

\author{
Luis Antonio Mello²
}

O turismo é uma temática que traz no seu bojo temas relevantes e que merecem consideração acadêmica, como sua importância econômica e seu impacto sobre economias, ambientes e sociedades. Sua importância não se resume em estatísticas apresentadas, mas, sobretudo, na sua incontestável capacidade de movimentar grupos sociais e condicionar a transformação e o ordenamento de territórios com vistas à sua realização. É notória a importância desse estudo para se identificar os impactos negativos e positivos procedentes da atividade turística sobre a sociedade e o ambiente, bem como, avaliar a possibilidade do estímulo, para que a mesma venha a se constituir em uma alternativa de desenvolvimento local para a área de estudo. Portanto, a presente pesquisa objetiva em síntese, compreender e avaliar - levando-se em consideração a área objeto de estudo - o papel que cabe ao turismo como importante fenômeno espacial, sociocultural e econômico do mundo contemporâneo, identificando sua capacidade na (re) produção do espaço e no desenvolvimento local. A metodologia adotada na pesquisa consiste na coleta, análise, apresentação e discussão de dados consultados e coletados em fontes primárias e secundárias. Aplicação de questionário, entrevistas e fotografias feitas in locu fazem parte das técnicas utilizadas para operacionalização do método. Quanto aos resultados preliminares, percebeu-se na área de estudo, que apesar do alto potencial levantado e, do interesse corrente da administração pública em estimular o turismo como ferramenta para o desenvolvimento local, enclaves políticos, visão economicista lucro imediato - por parte da população e dos empresários locais e, a própria sazonalidade dos turistas, condicionados pelo clima da região, fazem com que a atividade turística torne-se incipiente e figure em segundo plano nas estratégias de desenvolvimento dos municípios abrangidos pela investigação.

PALAVRAS-CHAVE: Turismo; desenvolvimento local; sociedade; ambiente.

\footnotetext{
${ }^{1}$ Orientador: Prof. Dr. Marcos Aurélio T. da Silveira

2 Mestrando em Geografia (UFPR) - e-mail: melbig2006@yahoo.com.br
} 